\title{
Synthesis and characterization of mixed ligand complexes of 8- hydroxy quinoline and Schiff base with some metal ions
}

\author{
Shayma.A.S.Alazawi* and Abbas.A.S.Alhamadani*
}

Date of acceptance 3/12/2006

\begin{abstract}
:
A new mixed ligand complexes have been prepared between 8- hydroxy quinoline and $o$-hydroxybenzylidene-1-phenyl-2,3-dimethyl-4-amino-3-pyrazolin-5-on with $\mathrm{Mn}(\mathrm{II}), \mathrm{Fe}(\mathrm{II}), \mathrm{Co}(\mathrm{II}), \mathrm{Ni}(\mathrm{II})$ and $\mathrm{Cu}$ (II) ions . the prepared complexes were isolated and characterized by (FT-IR)and (UV-Vis) spectroscopy. Elemental analysis (C.H.N) Flame atomic absorption technique . in addition to magnetic susceptibility and conductivity measurement.
\end{abstract}

\section{Introduction:}

Schiff bases are an important class of ligands in coordination chemistry and find extensive application in different fields ${ }^{(1-3)}$, Schiff bases derived from the salicylaldehydes are well known as polydentate ligands ${ }^{(4,5)}$.coordinating in neutral forms . In recent years metal complexes of Schiff bases have attracted considerable attention due to their remarkable antifungal, antibacterial and anti tumor activities ${ }^{(6,7)}$. Schiff bases complexes derived from 4-hydroxy salicylaldehyde and amines have strong anticancer activity ${ }^{(8)}$. In particular Merck company has successfully developed an antibacterial drug Cilastatin using chiral copper(II) Schiff base complexes derived from salicylaldehydes and chiral amine ${ }^{(9)}$. A search through literature ${ }^{(10-}$ ${ }^{15)}$ reveals that no work has been done on the transition metal complexes of the Schiff base $o$-hydroxybenzylidene-1phenyl-2,3-dimethyl-4-amino-3-

pyrazolin-5-on and 8-hydroxy quinoline. In this paper we presented here synthesis and characterization of some new $\mathrm{Mn}(\mathrm{II}), \mathrm{Fe}(\mathrm{II}), \mathrm{Co}(\mathrm{II}), \mathrm{Ni}$ (II) and $\mathrm{Cu}(\mathrm{II})$

complexes with these two ligands as mixed ligand complexes.

These complexes have been studied by (FT-IR) and (U.V-Vis) spectroscopy. Flame atomic absorption techniques, in addition to magnetic susceptibility and conductivity measurements.

Experimental:

Material and instrumentation: Metal salts $\left(\mathrm{MnCl}_{2} \cdot 4 \mathrm{H}_{2} \mathrm{O}, \mathrm{FeCl}_{2} \mathrm{XH}_{2} \mathrm{O}\right.$, $\mathrm{CoCl}_{2} \cdot 6 \mathrm{H}_{2} \mathrm{O}, \mathrm{NiCl}_{2} \cdot 6 \mathrm{H}_{2} \mathrm{O}, \mathrm{CuCl}_{2} \cdot 2 \mathrm{H}_{2} \mathrm{O}$ )

were obtained from Riedel - Dehaenage in high purity, salicylaldehydes, PAmino-2,3-dimethyl-1-phenyl-3-

pyrazolin-5-on , 8- hydroxy quinoline,ethanol , methanol and dimethyl foramaide from B.D.H.

\section{Physical measurements and analysis:}

Melting point were recorded on Gallen Kamp melting point apparatus and were uncorrected.FT-IR spectra were recorded as CsI discs using FT-IR.3800 Shimadzu in the range of $\left(4000-200 \mathrm{~cm}^{-1}\right)$. Electronic spectra were obtained using UV-160 shimadzu

* Chemistry department, College of sciences for woman University of Baghdad 
Spectrophotometer at room temperature $\left(10^{-3} \mathrm{M}\right)$ in DMF.Conductivity was measured by capacitor analyzer and in DMF solution $\left(1 \times 10^{-3} \mathrm{M}\right)$ at room temperature .elemental analysis (C.H.N) were performed by using a Carlo Erba 1106 elemental analyzer. Magnetic susceptibility measurements were obtained at $25 \mathrm{C}$ by Balance magnetic susceptibility model MSB-MK 1 . The metal percent in the complexes were determined by using the Hitachi Atomic Absorption .

\section{Preparation of the Schiff base (L):}

The Schiff base ligand was prepared by the condensation of the P-amino-2,3dimethyl-1-phenyl-3-pyrozoline-5-on $(0.5 \mathrm{~g}, 2.47 \mathrm{mmol})$ with the $(0.26 \mathrm{ml}, 2.47 \mathrm{mmol})$ salicylaldehyde in methanol $(15 \mathrm{ml})$.The resulting mixture was then refluxed for (1h) .The yellow precipitate formed was filtered and recrystalized from absolute ethanol to give yellow needles ${ }^{(14)}$.

\section{General method for preparation of the Complexes:}

To the aqeous solution of the metal salts $(0.5) \mathrm{gm}$ an ethanolic $\mathrm{KOH}$ solution of ligand (L) (0.64-1.06)gm (2.083.44)m.mole was added followed by the solution of ligand (Q) $(0.30-0.50) \mathrm{gm}$ (2.06-3.44)m.mole .dissolved in ethanolic $\mathrm{KOH}$.the reaction mixture was stirred continuously. the required product was shortly precipitated at room temperature. The precipitates were filtered off .washed with (1.1) (ethanol: water) crystallized from ethanol and dried at (60C). The table (1) shows the physical properties of the prepared Complexes.

\section{Results and Discussion:}

The physical properties and data of the Ligands (L) and (Q)with there metal Complexes are given in table (1).

The low values of molar conductivity $(\Omega)$ in DMF indicate the non .electrolyte behavior of these Complexes ${ }^{(16-19)}$

Table(1): Physical Characteristics and analytical data for $(L),(Q)$ and its metal complexes

\begin{tabular}{|c|c|c|c|c|c|c|c|c|}
\hline \multirow{2}{*}{ Compound } & \multirow{2}{*}{ Color } & \multirow{2}{*}{$\begin{array}{l}\text { Melting } \\
\text { Point C }\end{array}$} & \multirow{2}{*}{ Yield } & \multicolumn{4}{|c|}{$\mathrm{C}, \mathrm{H}, \mathrm{N}$ Analyses, found(calcd)(\%) } & \multirow{2}{*}{$\begin{array}{l}\text { Molar conductivity } \\
\mathrm{ohm}^{-1} \mathrm{~cm}^{2} \mathrm{~mol}^{-1}\end{array}$} \\
\hline & & & & \multicolumn{2}{|c|}{$\mathrm{M}$} & $\mathrm{H}$ & $\mathrm{N}$ & \\
\hline $\mathrm{L}$ & Yellow & $\begin{array}{c}189 \\
256\left(d^{*}\right)\end{array}$ & $85 \%$ & $(70.34)$ & $\begin{array}{l}9.8 \\
.34)\end{array}$ & $\begin{array}{r}6 \\
(5.5)\end{array}$ & $\begin{array}{r}13.1 \\
(13.67)\end{array}$ & 4.47 \\
\hline $\mathrm{Q}$ & White & 73 & & \multicolumn{4}{|c|}{-} & 12.258 \\
\hline$[\mathrm{Mn}(\mathrm{L})(\mathrm{Q})]$ & $\begin{array}{l}\text { Green } \\
\text { yellow }\end{array}$ & $260\left(d^{*}\right)$ & $65 \%$ & $\begin{array}{l}0.1 \\
(0.108)\end{array}$ & $\begin{array}{l}64.16 \\
(63.5)\end{array}$ & $\begin{array}{l}4.38 \\
(4)\end{array}$ & $\begin{array}{l}5.14 \\
(4.7)\end{array}$ & 15.2 \\
\hline$[\mathrm{Fe}(\mathrm{L})(\mathrm{Q})]$ & Dark green & $245\left(\mathrm{~d}^{*}\right)$ & $71 \%$ & $\begin{array}{l}0.125 \\
(0.11)\end{array}$ & $\begin{array}{l}64.04 \\
(64.8) \\
\end{array}$ & $\begin{array}{l}4.37 \\
(5.1) \\
\end{array}$ & $\begin{array}{l}5.13 \\
(5.5) \\
\end{array}$ & 16.888 \\
\hline$[\mathrm{Co}(\mathrm{L})(\mathrm{Q})]$ & $\begin{array}{l}\text { Green } \\
\text { yellow }\end{array}$ & $270\left(d^{*}\right)$ & $60 \%$ & $\begin{array}{r}0.13 \\
(0.11) \\
\end{array}$ & $\begin{array}{l}63.65 \\
(64) \\
\end{array}$ & $\begin{array}{r}4.34 \\
(4.6) \\
\end{array}$ & $\begin{array}{l}5.1 \\
(5.8) \\
\end{array}$ & 19 \\
\hline$[\mathrm{Ni}(\mathrm{L})(\mathrm{Q})]$ & $\begin{array}{l}\text { Yellow } \\
\text { green }\end{array}$ & $265\left(d^{*}\right)$ & $80 \%$ & $\begin{array}{c}0.1 \\
(0.115) \\
\end{array}$ & $\begin{array}{l}63.68 \\
(62.7) \\
\end{array}$ & $\begin{array}{l}4.35 \\
(3.9) \\
\end{array}$ & $\begin{array}{l}5.11 \\
(4.6) \\
\end{array}$ & 15.2 \\
\hline$[\mathrm{Cu}(\mathrm{L})(\mathrm{Q})]$ & Dark green & $225\left(\mathrm{~d}^{*}\right)$ & $62 \%$ & $\begin{array}{c}0.14 \\
(0.123)\end{array}$ & $\begin{array}{r}63.088 \\
(62.8) \\
\end{array}$ & $\begin{array}{l}4.3 \\
(4)\end{array}$ & $\begin{array}{l}5.06 \\
(4.9)\end{array}$ & 12.063 \\
\hline
\end{tabular}

$\left(\mathrm{d}^{*}\right)$ = Decomposition $\mathrm{Q}=8$ - hydroxy quinoline ,

$\mathrm{L}=o$-hydroxybenzylidene-1-phenyl-2,3-dimethyl-4-amino-3-pyrazolin-5-on

\section{Magnetic properties:}

The magnetic moment $\left(\mu_{\mathrm{eff}}\right)$ for the complexes of $\mathrm{Mn}^{+2},\left(\mathrm{~d}^{5}\right), \mathrm{Fe}^{+2}\left(\mathrm{~d}^{6}\right)$, and $\mathrm{Co}^{+2}\left(\mathrm{~d}^{7}\right)$ were found to be (4.656)B.M ,(4.7) B.M and (3.522) B.M respectively .within the expected spin- only values ${ }^{(20)}$. but the higher value of $\left(\mu_{\text {eff }}\right)$ of the
$\mathrm{Ni}^{+2}\left(\mathrm{~d}^{8}\right)$ complexes (3.9)B.M may be due to orbital contribution ${ }^{(21,22)}$.finally the $\left(\mu_{\text {eff }}\right)$ of the $\mathrm{Cu}^{+2}\left(\mathrm{~d}^{9}\right)$ complexes (1.884)B.M within the expected value for one electron . 
Table (2): The magnetic properties of the complexes at (25C)

\begin{tabular}{|c|c|c|c|c|c|c|c|c|c|}
\hline \multirow[b]{2}{*}{ Complexes } & \multirow{2}{*}{$\begin{array}{l}\text { No. of } \\
\text { electron }\end{array}$} & \multirow{2}{*}{$\begin{array}{l}\text { No. of } \\
\text { unpaired } \\
\text { electron }\end{array}$} & \multirow{2}{*}{$\begin{array}{c}\text { Electron } \\
\text { configuration }\end{array}$} & \multirow{2}{*}{$\begin{array}{c}\text { Term } \\
\text { symbol }\end{array}$} & \multirow{2}{*}{$\begin{array}{c}\text { Term } \\
\text { symbol } \\
\text { Ground } \\
\text { state in } \\
\text { Td }\end{array}$} & \multirow{2}{*}{$\begin{array}{c}\text { Orbital } \\
\text { contribution }\end{array}$} & \multicolumn{2}{|c|}{$\mu_{\text {eff }}$} & \multirow{2}{*}{$\begin{array}{c}\text { Suggested } \\
\text { structure }\end{array}$} \\
\hline & & & & & & & Found & calc & \\
\hline$[\mathrm{Mn}(\mathrm{L})(\mathrm{Q})]$ & $\mathrm{d}^{5}$ & 5 & $\mathrm{e}^{2} \mathrm{t}_{2}{ }^{3}$ & ${ }^{6} \mathrm{~S}$ & ${ }^{6} \mathrm{~A}_{1}$ & $\mathrm{NO}$ & 4.656 & 4.916 & Tetrahedral \\
\hline$[\mathrm{Fe}(\mathrm{L})(\mathrm{Q})]$ & $\mathrm{d}^{6}$ & 4 & $\mathrm{e}^{3} \mathrm{t}_{2}{ }^{3}$ & ${ }^{5} \mathrm{D}$ & ${ }^{5} \mathrm{E}$ & $\mathrm{NO}$ & 4.7 & 4.898 & Tetrahedral \\
\hline$[\mathrm{Co}(\mathrm{L})(\mathrm{Q})]$ & $\mathrm{d}^{7}$ & 3 & $\mathrm{e}^{4} \mathrm{t}_{2}{ }^{3}$ & ${ }^{4} \mathrm{~F}$ & ${ }^{4} \mathrm{~A}_{2}$ & $\mathrm{NO}$ & 3.522 & 3.872 & Tetrahedral \\
\hline$[\mathrm{Ni}(\mathrm{L})(\mathrm{Q})]$ & $\mathrm{d}^{8}$ & 2 & $\mathrm{e}^{4} \mathrm{t}_{2}{ }^{4}$ & ${ }^{3} \mathrm{~F}$ & ${ }^{3} \mathrm{~T}_{1}$ & Yes & 3.9 & 2.828 & Tetrahedral \\
\hline $\mathrm{Cu}(\mathrm{L})(\mathrm{Q})]$ & $\mathrm{d}^{9}$ & 1 & $\mathrm{e}^{4} \mathrm{t}_{2}{ }^{5}$ & ${ }^{2} \mathrm{D}$ & ${ }^{2} \mathrm{~T}_{2}$ & Yes & 1.884 & 1.732 & Tetrahedral \\
\hline
\end{tabular}

\section{The Electronic Spectra}

\section{(a)Electronic Spectra of free ligands:}

The spectrum of free ligand (L) showed a strong band at $\lambda \max (256 \mathrm{~nm})$ attributed to $\left(\pi \longrightarrow \pi^{*}\right)$ and another at $\lambda_{\max }(340,362 \mathrm{~nm})$ due to (n $\left.\longrightarrow \pi^{*}\right)^{(4) .}$

The 8- hydroxyl quinoline spectrum show absorption bands at $\lambda_{\max }$ $(294,307 \mathrm{~nm})$ respectively due to

$\left(\pi \longrightarrow \pi^{*}\right)$ and another bands of $\lambda_{\max }$ $(372,391 \mathrm{~nm})$ belongs to $\left(\mathrm{n} \longrightarrow \pi^{*}\right)^{(10)}$.

\section{Electronic Spectra of the complexes : $[\mathrm{Mn}(\mathrm{L})(\mathbf{Q})]$ Complexes:}

The Green-yellow complex showed strong bands at $\lambda_{\max }(296,345 \mathrm{~nm})$, these are attributed to charge transfer (C.T) and the shoulder at $\lambda_{\max }(351 \mathrm{~nm})$ due to ${ }^{6} \mathrm{~A}_{1} \longrightarrow{ }^{4} \mathrm{E}_{(\mathrm{D})}$ finally the band at $\lambda_{\max }$ (366nm) belong to ${ }^{6} \mathrm{~A}_{1} \longrightarrow{ }^{4} \mathrm{~T}_{2(\mathrm{D})}$, these values are accepted for tetrahedral complexes ${ }^{(23-25)}$.

\section{$[\mathrm{Fe}(\mathrm{L})(\mathrm{Q})]$ Complexes:}

The dark-green complex of iron (II) showed band at $\lambda_{\max }(351 \mathrm{~nm})$ belong to charge transfer and another bands at $\lambda_{\max }$ $(442,455 \mathrm{~nm})$ caused by the electronic transition ${ }^{5} \mathrm{E}_{(\mathrm{D})} \longrightarrow{ }^{5} \mathrm{~T}_{2(\mathrm{D})}{ }^{(23-27)}$.

\section{$[\mathrm{Co}(\mathrm{L})(\mathrm{Q})]$ Complexes:}

The Green-yellow complex of Cobalt (II) showed band at $\lambda_{\max }(277 \mathrm{~nm})$ attributed due to charge transfer (C.T) .and the other bands at $\lambda_{\max }(351,365 \mathrm{~nm})$ attributed to ${ }^{4} \mathrm{~A}_{2(\mathrm{~F})} \stackrel{\mathrm{v} 3}{\longrightarrow}{ }^{4} \mathrm{~T}_{1(\mathrm{P})}$ .transitions and the electronic transition of ${ }^{4} \mathrm{~A}_{2(\mathrm{~F})} \stackrel{\mathrm{v} 2}{\longrightarrow}{ }^{4} \mathrm{~T}_{1(\mathrm{~F})}$ was found at $\lambda_{\max }$ $(630 \mathrm{~nm})$, finally the absorption band at $\lambda_{\max }(715 \mathrm{~nm})$ is due to ${ }^{4} \mathrm{~A}_{2(\mathrm{~F})} \stackrel{\mathrm{v} 1}{\longrightarrow} \stackrel{4}{\longrightarrow} \mathrm{T}_{2(\mathrm{~F})}$ transitions ${ }^{(23-27)}$.

Accordingly the ligand field splitting energy, (10Dq) was taken as equal to the electronic transition ( $v 1)\left(13986.014 \mathrm{Cm}^{-}\right.$ ${ }^{1}$ ) and the reach inter electronic repulsion parameter $\left(\mathrm{B}^{\prime}\right)$ was found to be (123.907 $\mathrm{Cm}^{-1}$ ) from the relation$$
B^{\prime}
$$

$\left(\beta=\frac{B}{B^{0}}\right) \beta \quad$ was found to be equal to(0.127)

These parameters are accepted for Cobalt (II) Tetrahedral complexes ${ }^{(23-27)}$.

\section{[Ni(L)(Q)] Complexes:}

The electronic spectrum of yellowgreen complex of $\mathrm{Ni}$ (II) revealed the folloing electronic transition ${ }^{3} \mathrm{~T}_{1(\mathrm{~F})} \longrightarrow{ }^{3} \mathrm{~A}_{2(\mathrm{~F})}$ with (C.T), ${ }^{3} \mathrm{~T}_{1(\mathrm{~F})} \longrightarrow{ }^{3} \mathrm{~T}_{1(\mathrm{P})}$ and ${ }^{3} \mathrm{~T}_{1(\mathrm{~F})} \longrightarrow{ }^{3} \mathrm{~T}_{2(\mathrm{~F})}$ transitions at $\lambda_{\max }(381 \mathrm{~nm}), \lambda_{\max }$ $(514 \mathrm{~nm})$ and $\lambda_{\max }(820 \mathrm{~nm})$ respectively . The (10Dq) value for the complex was equal $\left(15243.902 \mathrm{Cm}^{-1}\right)$ and the $\left(B^{\prime}\right)$ value found to be $\left(607.733 \mathrm{Cm}^{-1}\right)(\beta)$ is equal to $(0.590)$. are characteristic for Tetrahedral complexes of $\mathrm{Ni}(\mathrm{II})^{(23-27)}$.

\section{$[\mathrm{Cu}(\mathrm{L})(\mathrm{Q})]$ Complexes:}

The spectrum of the dark-green complex of $\mathrm{Cu}(\mathrm{II})$ showed very strong band at $\lambda_{\max }(270 \mathrm{~nm})$ which belongs to the charge transfer, the shoulder found in the visible region at $\lambda_{\max }(430 \mathrm{~nm})$ was attribute to the electronic transition ${ }^{2} \mathrm{~T}_{2(\mathrm{D})} \longrightarrow \mathrm{C}^{2} \mathrm{E}_{(\mathrm{D})}{ }^{(23-28)}$.

All transitions with their a assignments are summarized in Table (3). 
Table (3): U.V-Visible Spectra of free Ligand and their Complexes $\left(10^{-3}\right) \mathrm{M}$ in DMF

\begin{tabular}{|c|c|c|c|c|c|c|}
\hline Compounds & $\lambda_{\max } \mathrm{nm}$ & ABS & $\begin{array}{l}\text { Wave number } \\
\qquad \mathrm{Cm}^{-1}\end{array}$ & $\begin{array}{l}\varepsilon_{\max } \\
\left(\mathrm{L} \cdot \mathrm{mol}^{1} \cdot \mathrm{Cm}^{1}\right)\end{array}$ & Transitions & Remarks \\
\hline $\mathrm{L}$ & $\begin{array}{l}256 \\
340 \\
362 \\
\end{array}$ & $\begin{array}{l}2.632 \\
4.458 \\
2.354 \\
\end{array}$ & $\begin{array}{c}39062.5 \\
29411.764 \\
27624.306 \\
\end{array}$ & $\begin{array}{l}2632 \\
4458 \\
2358 \\
\end{array}$ & $\begin{array}{l}\pi \longrightarrow \pi^{*} \\
\mathrm{n} \longrightarrow \pi^{*} \\
\mathrm{n} \longrightarrow \pi^{*}\end{array}$ & - \\
\hline $\mathrm{Q}$ & $\begin{array}{l}294 \\
307 \\
372 \\
391\end{array}$ & $\begin{array}{l}2.500 \\
1.370 \\
0.027 \\
0.037\end{array}$ & $\begin{array}{c}34013.605 \\
32573.289 \\
26881.72 \\
25575.447\end{array}$ & $\begin{array}{c}2500 \\
1370 \\
27 \\
37\end{array}$ & $\begin{array}{l}\pi \longrightarrow \pi^{*} \\
\pi \longrightarrow \pi^{*} \\
\mathrm{n} \longrightarrow \pi^{*} \\
\mathrm{n} \longrightarrow \pi^{*}\end{array}$ & \\
\hline$[\mathrm{Mn}(\mathrm{L})(\mathrm{Q})]$ & $\begin{array}{l}296 \\
345 \\
351 \\
366\end{array}$ & $\begin{array}{l}1.235 \\
2.500 \\
0.882 \\
0.946\end{array}$ & $\begin{array}{l}33783.783 \\
28985.507 \\
28490.028 \\
27322.404\end{array}$ & $\begin{array}{c}1235 \\
2500 \\
882 \\
946\end{array}$ & $\begin{array}{c}(\mathrm{C} . \mathrm{T}) \\
{ }^{6} \mathrm{~A}_{1} \stackrel{(\mathrm{C} . \mathrm{T})}{\longrightarrow}{ }^{4} \mathrm{E}_{(\mathrm{D})} \\
{ }^{6} \mathrm{~A}_{1} \longrightarrow \mathrm{T}_{2(\mathrm{D})}\end{array}$ & $\begin{array}{l}- \\
- \\
-\end{array}$ \\
\hline \multirow[t]{4}{*}[\mathrm{Fe}(\mathrm{L})(\mathrm{Q})]{} & 351 & 0.779 & 28490.028 & 779 & (C.T) & New band \\
\hline & 361 & 0.814 & 27700.831 & 814 & $\mathrm{n} \longrightarrow \pi^{*}$ & Hypo chromic effect \\
\hline & 416 & 0.148 & 24038.461 & 148 & 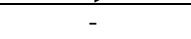 & Red shift \\
\hline & $\begin{array}{l}442 \\
455\end{array}$ & $\begin{array}{l}1.796 \\
0.178\end{array}$ & $\begin{array}{l}22624.434 \\
21978.022\end{array}$ & $\begin{array}{c}1796 \\
178\end{array}$ & ${ }^{5} \mathrm{E}_{(\mathrm{D})} \longrightarrow{ }^{5} \mathrm{~T}_{2(\mathrm{D})}$ & New band \\
\hline \multirow[t]{5}{*}[\mathrm{Co}(\mathrm{L})(\mathrm{Q})]{} & 244 & 0.143 & 40983.606 & 143 & - & $\begin{array}{c}\text { Blue shift with Hypo chromic } \\
\text { effect }\end{array}$ \\
\hline & 277 & 1.859 & 36101.083 & 1859 & (C.T) & New band \\
\hline & $\begin{array}{l}351 \\
365\end{array}$ & $\begin{array}{l}0.896 \\
0.966\end{array}$ & $\begin{array}{c}28490.028 \\
27397.26\end{array}$ & $\begin{array}{l}896 \\
966\end{array}$ & ${ }^{4} \mathrm{~A}_{2(\mathrm{~F})} \stackrel{\mathrm{v} 3}{\longrightarrow}{ }^{4} \mathrm{~T}_{1(\mathrm{P})}$ & Corresponding with (C.T) \\
\hline & 630 & 0.016 & 15873.015 & 16 & ${ }^{4} \mathrm{~A}_{2(\mathrm{~F})} \stackrel{\mathrm{v} 2}{\longrightarrow}{ }^{4} \mathrm{~T}_{1(\mathrm{~F})}$ & New band \\
\hline & 715 & 0.022 & 13986.014 & 22 & ${ }^{4} \mathrm{~A}_{2(\mathrm{~F})} \stackrel{\mathrm{vl}}{\longrightarrow}{ }^{4} \mathrm{~T}_{2(\mathrm{~F})}$ & New band \\
\hline \multirow[t]{5}{*}[\mathrm{Ni}(\mathrm{L})(\mathrm{Q})]{} & 304 & 0.665 & 32894.736 & 665 & - & Blue shift \\
\hline & 358 & 0.763 & 27932.96 & 763 & (C.T) & New band \\
\hline & 381 & 1.200 & 26246.719 & 1200 & ${ }^{3} \mathrm{~T}_{1(\mathrm{~F})} \longrightarrow{ }^{3} \mathrm{~A}_{2(\mathrm{~F})}$ & Corresponding with(C.T) \\
\hline & 514 & 0.063 & 19455.252 & 63 & ${ }^{3} \mathrm{~T}_{1(\mathrm{~F})} \longrightarrow{ }^{3} \mathrm{~T}_{1(\mathrm{P})}$ & New band \\
\hline & 820 & 0.044 & 12195.122 & 44 & ${ }^{3} \mathrm{~T}_{1(\mathrm{~F})} \longrightarrow \mathrm{T}_{2(\mathrm{~F})}$ & New band \\
\hline \multirow[t]{3}{*}[\mathrm{Cu}(\mathrm{L})(\mathrm{Q})]{} & 270 & 1.143 & 37037.037 & 1143 & (C.T) & New band \\
\hline & 312 & 0.912 & 32051.282 & 912 & - & Red shift \\
\hline & 430 & 0.024 & 23255.813 & 24 & ${ }^{2} \mathrm{~T}_{2(\mathrm{D})} \stackrel{{ }^{2}}{\mathrm{Z}_{(\mathrm{D})}}$ & New band \\
\hline
\end{tabular}

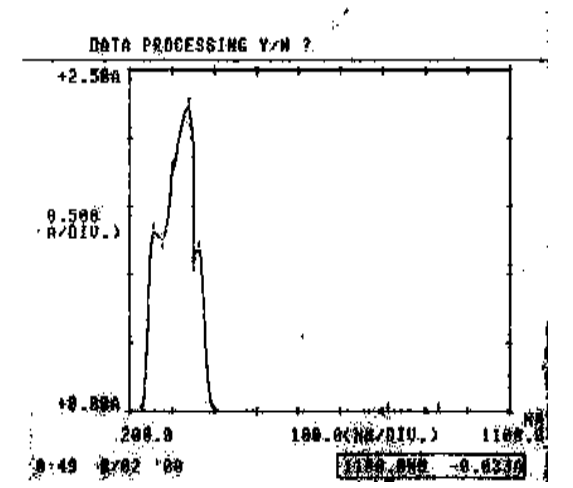

Spectra (3)U.V-Visible spectrum of free Ligand (L)

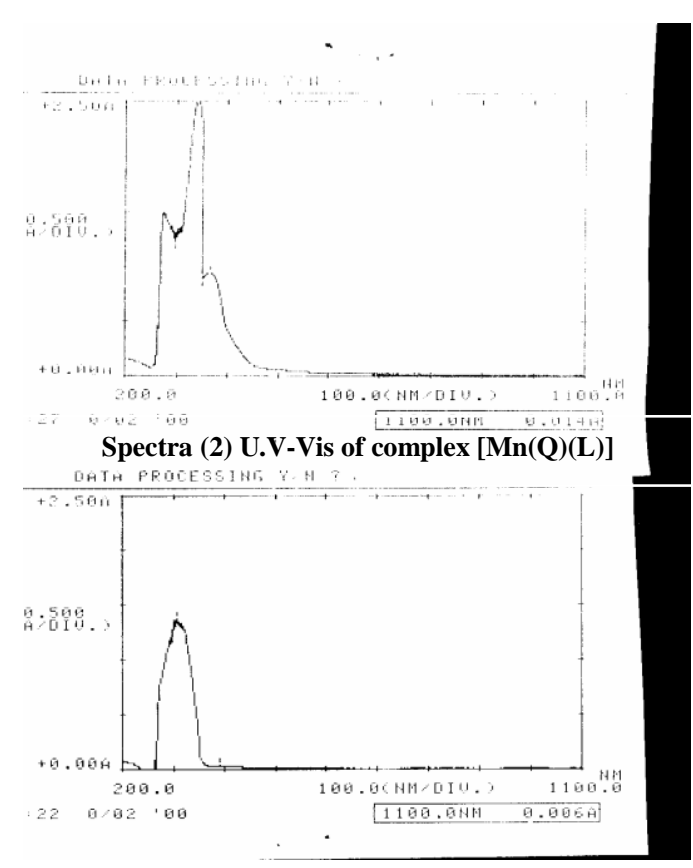

Spectra (3) U.V-Vis of 8-hydreoxy quinoline 
Infrared spectral studies :

Infrared spectra of free ligands:

The characteristic vibrations and assignments of ligand (L) and (Q) and their complexes as $\mathrm{C}_{\mathrm{s}} \mathrm{I}$ disc are described in table (4).

The spectrum of ligand (L) exhibited weak bands at $3465 \mathrm{Cm}^{-1}$ and $(3060) \mathrm{Cm}^{-}$ ${ }^{1}$ attributed to the stretching vibration of $v(\mathrm{O}-\mathrm{H})$ and $v(\mathrm{C}-\mathrm{H})$ aromatic respectively $(9,14,29)$,but the strong band at $(1656) \mathrm{Cm}^{-}$ ${ }^{1}$ belong to str.vibr $v(\mathrm{C}==\mathrm{O})$ and the another strong bands belong to the str.vibr $v(\mathrm{C}==\mathrm{N}), v(\mathrm{C}==\mathrm{C})$ and $v(\mathrm{C}-$ O) was found at $(1600) \mathrm{Cm}^{-1},(1490) \mathrm{Cm}^{-}$ ${ }^{1}$ and (1265) $\mathrm{Cm}^{-1}$ respectively (29-32)

In the spectrum of ligand (Q) was noticed broad band at (3213) $\mathrm{Cm}^{-}$ ${ }^{1}$ attributed to str. Vib $v(\mathrm{OH})$ with shoulder at (3074) $\mathrm{Cm}^{-1}$ due to str . vibr $v(\mathrm{C}-\mathrm{H})$ aromatic and the another strong bands appeared at (1577) $\mathrm{Cm}^{-1},(1500)$ $\mathrm{Cm}^{-1}$ and (1284) $\mathrm{Cm}^{-1}$ attributed str. Vibr $v(\mathrm{C}=\mathrm{N}) \cdot v(\mathrm{C}=\mathrm{C})$ and $v(\mathrm{C}-\mathrm{O})$ 13,33)

\section{Infrared spectra of Complexes:}

The infrared spectra of the prepared Complexes exhibited str .vibr. $v(\mathrm{C}=\mathrm{N})$ in the range (1591-1597) $\mathrm{Cm}^{-1}$ show shifting to the lower frequencies by $(9-7) \mathrm{Cm}^{-1}$ in Comparison with ligand (L) .but with ligand $(\mathrm{Q})$ the shafting was between (1416) to the higher frequencies which indicated the coordination of ligands with metal ions through the nitrogen atoms in their structure . and the another bands appeared . in the range (11221130) $\mathrm{Cm}^{-1}$ belong to the str . vibr $v(\mathrm{C}$ $\mathrm{O})$ was shifted to the lower frequencies by (143-135) $\mathrm{Cm}^{-1}$ and (162-154) $\mathrm{Cm}^{-1}$ in Comparison with ligands (L) and(Q) respectively the disappearing of band for $v(\mathrm{OH})$ vibration in the spectar of Complexes indicating Coordination of phinolic oxygen with metal ions ${ }^{(31,33,34)}$.

The spectra bands of complexes at (1656) $\mathrm{Cm}^{-1}$ was characteristic for the carbonyl group which did not Sutter a shift, suggesting that the oxygen atom of the carbonyl group is not Coordinated to the metal ion ${ }^{(31,33)}$.

\section{M-ligand bonds:}

The infrared of prepared complexes showed weak bands in the range (501-509) $\mathrm{Cm}^{-1}$ and (445-452) $\mathrm{Cm}^{-}$ ${ }^{1}$ was attributed to the str.vibr of $v(\mathrm{M}-\mathrm{O})$ and $v(\mathrm{M}-\mathrm{N})$ respectively .

Table (4) the characteristic bands of Infrared spectra of the ligand s and their complexes

\begin{tabular}{|c|c|c|c|c|c|c|c|c|}
\hline Compounds & $\mathrm{v}(\mathrm{O}-\mathrm{H})$ & $\mathrm{v}(\mathrm{C}-\mathrm{H}) \mathrm{ar}$ & $v(C=O)$ & $v(C=N)$ & $\mathbf{v}(\mathrm{C}=\mathrm{C})$ & $v(C-O)$ & $v(\mathbf{M}-\mathrm{O})$ & $v(M-N)$ \\
\hline $\mathbf{Q}$ & $\begin{array}{c}3213 \\
\mathrm{~b}\end{array}$ & $\begin{array}{l}3074 \\
\text { sho }\end{array}$ & - & - & $\begin{array}{c}1500 \\
\text { v.s }\end{array}$ & $\begin{array}{c}1215 \\
\mathrm{~s}\end{array}$ & - & - \\
\hline $\mathbf{L}$ & $\begin{array}{c}3465 \\
w\end{array}$ & $\begin{array}{c}3060 \\
w\end{array}$ & $\begin{array}{l}1654 \\
\text { v.s }\end{array}$ & $\begin{array}{c}1600 \\
\mathrm{~s}\end{array}$ & $\begin{array}{c}1490 \\
\mathrm{~s}\end{array}$ & $\begin{array}{c}1265 \\
\mathrm{~s}\end{array}$ & - & \\
\hline$[\mathbf{M n}(\mathbf{L})(\mathbf{Q})]$ & - & $\begin{array}{l}3062 \\
\text { sho }\end{array}$ & $\begin{array}{c}1651 \\
\mathrm{~s}\end{array}$ & $\begin{array}{l}1593 \\
\text { sho }\end{array}$ & $\begin{array}{c}1481 \\
\mathrm{~s}\end{array}$ & $\begin{array}{c}1130 \\
\mathrm{~m}\end{array}$ & $\begin{array}{l}445 \\
w\end{array}$ & $\begin{array}{l}501 \\
w\end{array}$ \\
\hline$[\mathbf{F e}(\mathbf{L})(\mathbf{Q})]$ & - & $\begin{array}{l}3074 \\
\text { v.w }\end{array}$ & $\begin{array}{c}1655 \\
\mathrm{~m}\end{array}$ & $\begin{array}{l}1593 \\
\text { sho }\end{array}$ & $\begin{array}{c}1481 \\
\mathrm{~m}\end{array}$ & $\begin{array}{c}1130 \\
\mathrm{~m}\end{array}$ & $\begin{array}{l}452 \\
w\end{array}$ & $\begin{array}{l}502 \\
w\end{array}$ \\
\hline$[\operatorname{Co}(L)(Q)]$ & & $\begin{array}{l}3050 \\
\text { v.w }\end{array}$ & $\begin{array}{c}1653 \\
\text { vs }\end{array}$ & $\begin{array}{l}1591 \\
\text { sho }\end{array}$ & $\begin{array}{c}1481 \\
\mathrm{~m}\end{array}$ & $\begin{array}{c}1126 \\
\mathrm{w}\end{array}$ & $\begin{array}{l}451 \\
w\end{array}$ & $\begin{array}{l}505 \\
w\end{array}$ \\
\hline$[\mathbf{N i}(\mathbf{L})(\mathbf{Q})]$ & - & $\begin{array}{l}3070 \\
\text { v.w }\end{array}$ & $\begin{array}{c}1654 \\
w\end{array}$ & $\begin{array}{c}1593 \\
w\end{array}$ & $\begin{array}{c}1481 \\
\mathrm{w}\end{array}$ & $\begin{array}{c}1122 \\
w\end{array}$ & $\begin{array}{l}448 \\
\mathrm{vw}\end{array}$ & $\begin{array}{l}509 \\
w\end{array}$ \\
\hline $\mathbf{C u}(\mathbf{L})(\mathbf{Q})]$ & - & $\begin{array}{c}3065 \\
w\end{array}$ & $\begin{array}{c}1655 \\
w\end{array}$ & $\begin{array}{c}1592 \\
w\end{array}$ & $\begin{array}{c}1481 \\
\mathrm{w}\end{array}$ & $\begin{array}{l}1130 \\
\mathrm{vw}\end{array}$ & $\begin{array}{l}450 \\
w\end{array}$ & $\begin{array}{l}501 \\
w\end{array}$ \\
\hline
\end{tabular}

$\mathrm{S}=$ strong, $\mathrm{m}=$ medium, $\mathrm{w}=$ =weak, $\mathrm{sho=}$ shoulder, $\mathrm{v}=$ =very, $\mathrm{b}=$ broad 


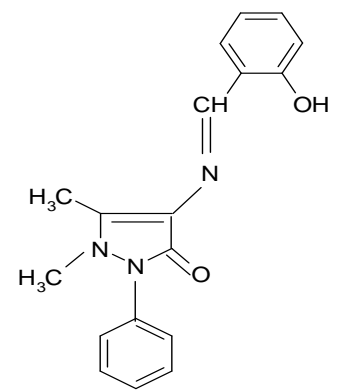

Fig. (1) Structure of the Ligand (L)

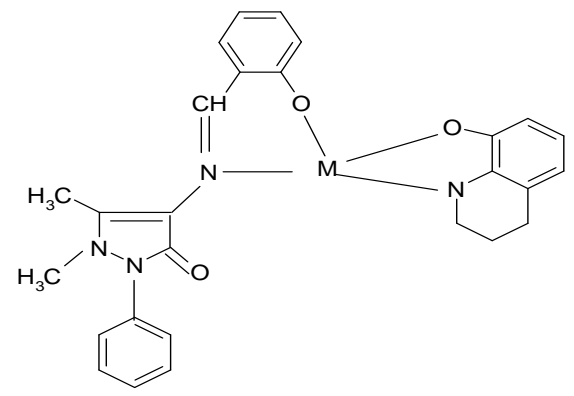

Fig. (2) Suggested Structure of the tetrahedral complexes

(M=Mn(II),Fe(II), Co(II), Ni(II)andCu(II))

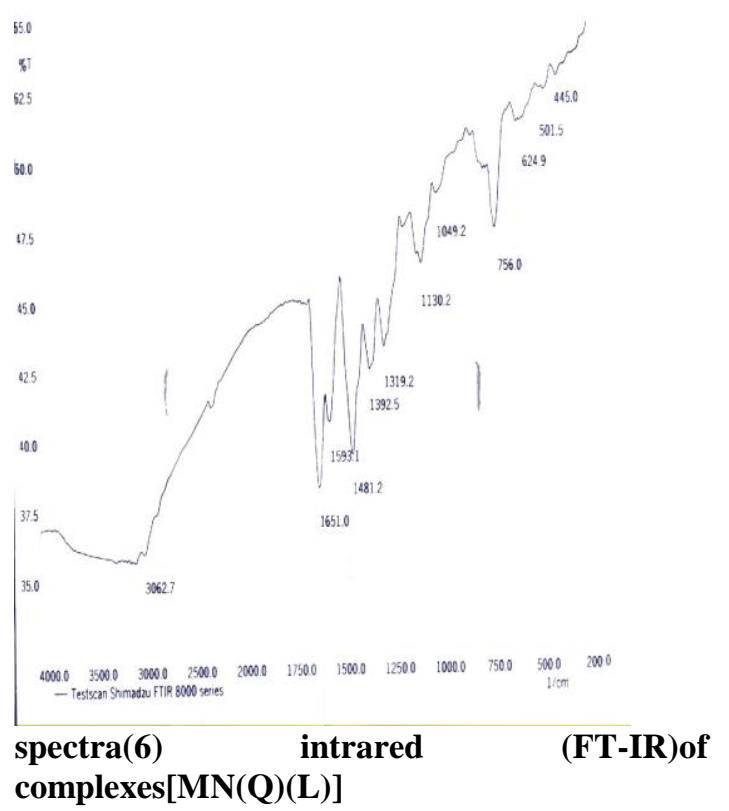

\section{References:}

1- Hughes,M.N.1984.The

Inorganic Chemistry of Biological processes, $2^{\text {nd }}$ Edn., Wiley .

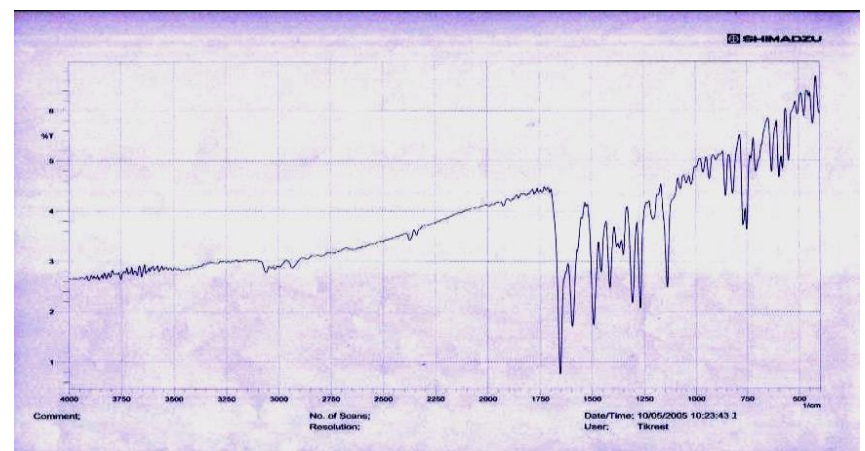

Spectra (4) Infrared (FT-IR) of Schiff base (L)

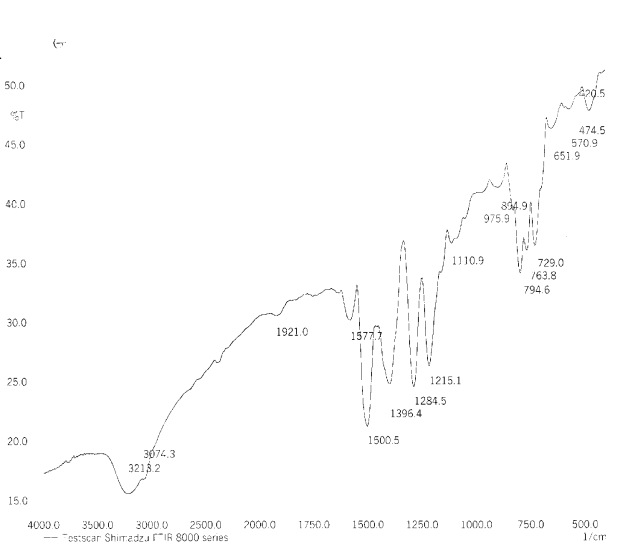

Spectra (5) Infrared (FT-IR) of 8-hydreoxy quinoline

2- $\quad$ Eichhorn,G.L and Marzilli,L.G.1994.Advances in Inorganic Biochemistry, models in Inorganic chemistry,PTR prenticeHall,Inc.

3- $\quad$ Tarafder,M.H Saravanan,N Crouse,K.A and Ali,A.M.2001.Coordination chemistry and biological activity of $\mathrm{Ni}(\mathrm{II})$ and $\mathrm{Cu}$ (II) ion complexes with nitrogensulphur donor ligands derivedfrom $\mathbf{S}$ benzyldit , Transition metal chemistry.,26,(6):613-618.

4- $\quad$ Sonmez,M and Sekerci,M .2002. synthesis and characterization of $\mathrm{Zn}(\mathrm{II}), \mathrm{Co}(\mathrm{II}), \mathrm{Ni}(\mathrm{II})$ and $\mathrm{Cu}(\mathrm{II})$ Schiff basees complexes from 1-Amino-5benzoyl-4-phenyl-1H-pyrimidine-2one with salicylaldehyde ,polish.J.chem.,76:907-914.

5- Vukadin,M.L Ljijanas,V Katalin,M.S and Valerijal,C.2003. Transition metal complexes with 
thiosemicarbazide-based ligands . Part 46-Synthesis and physico- chemical characterization of mixed ligand Cobalt(III) -complexes with salicylaldehyde semi-thiosemi and isothiosemicarbazone and pyridine,J.Serb.Chem.Soc.,68,(12):919927.

6- Chakravarty,A.R Nreddy,A.P Santra,B.K and Thomas,A.M .2002 .Copper Complexes as chemical Nucleases.,

J.Indian.chem.Sci,114,(4):319-401.

7- Hanna,W.G and Moaead,M.M.2001. synthesis and characterization and Antimicrobialoge Activity of $\mathrm{Co}(\mathrm{II}), \mathrm{Ni}$ (II) and $\mathrm{Cu}(\mathrm{II})$ complexes with new Asymmetrical Schiff base ligand, Transition metal chemistry ,26,(6):644-651.

8- Keypour,H Salehzadeh,S and Parish,R. V. 2002. Synthesis of two potentially heptadentate $\left(\mathrm{N}_{4} \mathrm{O}_{3}\right)$ Schiff base ligand derived from condensation of Tris-(3-amino propyl)-amine and Salicylaldehyde or 4-hydroxy Salicylaldehyde $\mathrm{Ni}$ (II) and $\mathrm{Cu}$ (II) complexes of the former ligand ., J. Molecules. 7: 140-144.

9- Gao, W.T and Zheng, Z. 2002. synthesis studies on optically active Schiff base ligands derived from condensation of 2-hydroxy acetophenone and chiral di amine., $J$. Molecules. 7: 511-516.

10- Ahn,G Ware,D.C Denny,W.A and Wilson,W.R.2004.Optimization of the auxiliary ligand shell of Cobalt (III) (8- hydroxy quinoline) complexes as model hypoxia-selective radiationactivated prodrugs. Radiat.res., in press.

11- Mitsunobu,N Chitoshi,K Hiotmi,u Kazushige, $Y$ and Akio,Y.2005.Crystal structure of 8- hydroxy quinoline-2carboxylic acid Copper complexes. Analytical Sciences.,21:X115-X116.

12- Rai,S.B Muthiah,P.T Bocelli,G and Righi,L.2001 Tetra aqua (8- hydroxy quinoline-5-sulfonatoN,O)Nickel(II)

monohydrate;Acta.Cryst.,57,(12):591-

594.

13- Giraudi,G

Baggiani,C

Anfossi,L Tozzi,C Giorannoli,C and Vanni,A.2001.The complexation of mercury (II) and organomercurial compounds by 8- hydroxy quinolinebovine serum albumin Conjugates, Ann.chim.91:541-551.

14- Alhamadani,A.A.S.2005.Synthes is andCharacterizationof $\mathrm{Co}(\mathrm{II})$, $\mathrm{Ni}(\mathrm{II}), \mathrm{Cu}(\mathrm{II})$ and $\mathrm{Zn}(\mathrm{II})$ Schiff Base Complexes with hydroxybenzylidene-1-phenyl-2,3dimethyl-4-amino-3-pyrazolin-5on.,J.Um-Salamafor

Science.,2,(2):395-602.

15- Rajib,L.D Indrajit,B

Subhadra,G and Alko,M.2002. Synthesis and reactivity of the Copper (II) Complexes of $\mathrm{N}-\alpha$ acetophenyl-X-salicylaldimines $(\alpha=4$ or 3, $\mathrm{X}=\mathrm{H}, 5-\mathrm{Br}$ or 3-COOH). Molecular structure of bis (N-4actophenyl-salicylaldiminato)

Copper(II). Indian.J .of chemistry ,41A:1380-1384.

16- Kettle,S.F.A.1975.Coordination Compounds, Thomas Nelson and Sons.London.,165.

17- Cezar,S Angela,K. 2000.Co(II) ,Ni(II) and $\mathrm{Cu}$ (II) Complexes of bidentate Schiff bases., ActaChim.Slov.47:179-185.

18- Sutton,D1968Electronic Spectra of Transition metal Complexes",$M c$ Graw-Hill publishing Compony litd .

19- Burger,K 1973."Coordination Chemistry",Expermental Methods , London Bult/Worths and Co(publishers)ltd.

20- Nicholls,D.1984 "Complexes and First Row Transition Elements", Translated by Dr.Wissam ibrahim Azeez, Mosul University .

21- Day,M.C and Selbin,J.1983."'Theoretical Inorganic chemistry " Transition Elements", 
Translated by Dr.Issam, Mosul

University

22- Cotton,F.A

and

Wilkinson,G.1998."Advanced

Inorganic chemistry ".Wiley-inter science,New.York.

23- Lever, A.B.P.1984. Inorganic Electronic Spectroscopy., Elsevier. Amsterdam.

24- Dunn, T.M.1960. The Visible and Ultraviolet spectra of complex Compounds in modern Coordination Chemistry., New York; Inter Science.

25- Kirchner, R. M Mealli, C Baily, $M$ House, N Torrel, L.P Wilson, L. J Andrews, L.C Rose, N. $\mathrm{J}$ and Lingafelter, E.C. 1987. The Variable Coordination Chemistry of a.transition metal ions the chemistry and structures of $\left[\mathrm{py}_{3} \mathrm{tren}\right]^{2+}$, where $\mathrm{M}(\mathrm{II})=\mathrm{Mn}, \mathrm{Fe}, \mathrm{Co}, \mathrm{Ni}, \mathrm{Cu}$, and $\mathrm{Zn}$ $\left(\right.$ py $_{3}$ tren $) \quad=\quad N\{$ $\left.\mathbf{C H}_{2} \mathbf{C H}_{2} \mathbf{N}=\mathbf{C H}\left(\mathbf{C}_{6} \mathbf{H}_{4} \mathbf{N}\right)\right\}_{3}$,, coord. Chem.. Rev. 77: 89-163.

26- Duward,F.S and

Atkins,P.W.1990."Inorganic

Chemistry" Oxford University Press. 27- Al-Hashimi,S.M Sarhan,B.M and Salman,A.W.2002."Synthesis and characterization of complexes of $\mathrm{N}$ acetyl-DL-tryptophane with some metal ions".Iraq.J.Chem;28(1):1-11.
28- Dakhyl, A.B.2001. Spectral study of some Schiff base., Salah al deen Univ . College of Education Tikrit. Iraq. 29- Bellamy,L.J.1978.The Infrared Spectra of complex Molecules., chapman and Hall, London.

30- Ali,A.K Kamellia, $\mathrm{N}$ and Zolfaghar, R.2005. syntheses Characterizations and study of the Oxidation of styrene by Molecular Oxygen., J. Molecules. 10:302-311.

31- Silverstein, R.M Bassler,G.C and Movril, T.C. 1981. Spectroscopic identification of Organic Compounds., 4thedn; New York; Wiley. 32- Ravichandran,N.S and Thangaraja, C. 2004. Copper (II), Cobalt (II), Nickel (II) and Zinc (II) complexes of Schiff base derived from benzyl-2,4-dinitro phenyl hydrazones with aniline., J. chem.. Sci. 116 (4): 215-219.

33- Nakamoto,N .1986."Infrared Spectra of Inorganic Coordination Compounds" $4^{\text {th }}$ Ed. Wiley, Inter science, New York.

34- Nakamoto, K.1997."Infrared and Raman Spectra of Inorganic and coordination compounds". Wiley-Inter.Science,New York

\section{تحضير وتشخيص معقدات الليكاتدات المختلطة من 8 ـ هايدروكسي كوينولين وقاعدة شف مع بعض الايونات القلزية

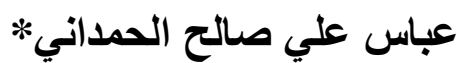$$
\text { * شيماء احمد شاكر العزاوي }
$$$$
\text { *قتم الكيمياء كلية العلوم للبنات جامعة بغداد }
$$

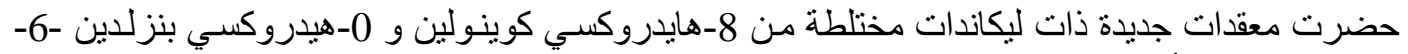

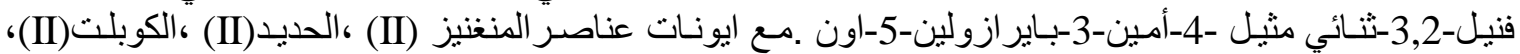

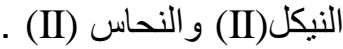

عزلت المركبات المحضرة وتم تشخيصها باستخدام طيف الأشـعة تحت الحمر اءو وطيف الأشعة فوق البنفسجيةـ

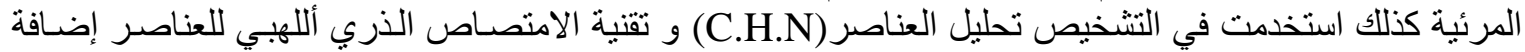
إلى قياسات الحساسية المغناطيسية و التوصيلية الكهربائية . 